\title{
Education and Mentoring About Cyberbullying Through Law of Information and Electronic Transaction and Islamic Teaching to "Generation Z"
}

\section{Pinastika Prajna Paramita ${ }^{1}$, Isdiyana Kusuma Ayu ${ }^{2}$, Muntaha ${ }^{3}$, Rangga Sa'adillah}

S.A.P. ${ }^{4}$

1 Universitas Islam Malang

${ }^{2}$ Universitas Islam Malang

${ }^{3}$ STIKES Widyagama Husada Malang

${ }^{4}$ STAI Taswirul Afkar Surabaya

E-mail: pinastika.pp@unisma.ac.id, Isdiyana@unisma.ac.id,

muntaha@widyagamahusada.ac.id,rangga@staitaswirulafkar.ac.id

\section{Article History:}

Received: July $10^{\text {th }} 2020$

Revised: Aug $2^{\text {nd }} 2021$

Accepted: Nov 31 2021
Keywords:

Cyberbullying; UU-ITE;

Cyberbullying dalam Islam;

Generasi $Z$

\begin{abstract}
The purposes of this mentoring are obtained education about perspective of cyberbullying through Law of Information and Electronical Transaction (A.K.A. UU ITE) and Fatwa MUI Number 24 Year 2017 to students that incidentally called "Generation Z", a generation that cannot be separated from social media in their lives. The method that used in this mentoring is education in the form of training with model of participatory. It educates more motivating participants actively, not only knowledge transferring but it emphasizes on question and answers, discussion and reflection even though the interest of the students is limit, considering those activities were conducted on Zoom Application. This mentoring was succeeded to change the point of view of students that cyberbullying is a common view, cyber joke is a behaviour that must be avoided because it has an impact on juvenile delinquency, adult crime, domestic violence and suicide. It also creates friendship feud).
\end{abstract}

\section{Introduction}

Generation $\mathrm{Z}$ or also called iGeneration or internet generation is the first real global generation ${ }^{1}$. They have grown up in an uncertain and complex environment that defines their views on work, study and the world. They have different expectations in their workplace, for instance career oriented, ambitious professional generation, and

1 Tanuar Surya Putra, “Theoritical Review: Teori Perbedaan Generasi," Among Makarti 9, no. 18 (2016): 123-134. 
high level of linguistic technical skill. This generation is also multitasking. According to population census 2020, there are 27,94\% of Generation Z from 270,2 million of Indonesian society that is very potential to affect Indonesia in the future ${ }^{2}$.

This generation was born when the information access was become global culture, and also affecting values of views and goals of life ${ }^{3}$. For generation $\mathrm{Z}$, real and virtual life are inseparable. Cyber world is also increasing the development of technology with any human creativity and everything can be done and resolved with technology.

On the other hand, Generation $\mathrm{Z}$ is very vulnerable to suffering from mild emotional mental disorders, such as anxiety and depression. At first, this disorder is being underestimated because it tends to be a normal disease for instance feelings of unhappiness, pain and humiliation, confusion, distress, loss of self-esteem, anxiety, insecurity, and loss of concentration, contributing to low attendance and low academic achievement 4 . However, if this situation continuous, it may cause serious social problems such as bullying 6 , increased juvenile delinquency, adult crime ${ }^{7}$, domestic violence, and suicide ${ }^{8}$.

Bullying is a form of mental disorder that cannot be underestimated, the impact can be physical and mental disorder at the same time, causing fear and psychological disturbances, lead to revenge even endanger lives or death ${ }^{9}$. Moreover, bullying is a criminal act because it violates Human Rights. Cyber bullying is only occurred in children, because cyberbullying is only valid if the suspect and victim are below 18 years old or legally incapable according to the law. Otherwise, if one of them or both are over 18 years old, the case will be categorized as cyber stalking or cyber harassment ${ }^{10}$.

This condition will extremely worried if Generation $\mathrm{Z}$ cannot manage Internet

\footnotetext{
2 Badan Pusat Statistik, Hasil Sensus Penduduk 2020 (Jakarta Pusat, 2021).

3 Putra, "Theoritical Review: Teori Perbedaan Generasi."

4 Indah Budiati et al., Statistik Gender Tematik: Profil Generasi Milenial Indonesia (Jakarta Pusat: Kementerian Pemberdayaan Perempuan dan Perlindungan Anak, 2018).

5 Ipah Saripah and Ajeng Nurul Pratita, "Kecenderungan Perilaku Cyberbullying Peserta Didik Berdasarkan Jenis Kelamin,” Pedagogia: Jurnal Ilmu Pendidikan 16, no. 3 (2018): 180-192.

${ }^{6}$ Ari Susanti, "Sosialisasi Bahaya Cyberbullying Pada Remaja (Perspektif Islam Dan Patologi Sosial )," Jurnal Pengabdian Masyarakat Ipteks 6, no. 1 (2020): 21-27.

7 Saripah and Pratita, "Kecenderungan Perilaku Cyberbullying Peserta Didik Berdasarkan Jenis Kelamin."

${ }^{8}$ Budiati et al., Statistik Gender Tematik: Profil Generasi Milenial Indonesia.

${ }^{9}$ Suardi and Sulaiman Samad, "Edukasi Pencegahan Perundungan," in Seminar Nasional Hasil Pengabdian Kepada Masyarakat "Peluang Dan Tantangan Pengabdian Kepada Masyarakat Yang Inovatif Di Era Kebiasaan Baru” (Makasar: Universitas Negeri Makasar, 2020), 569.

10 Subaidah Ratna Juita, Amri Panahatan Sihotang, and Ariyono, "Cyber Bullying Pada Anak Dalam Perspektif Politik Hukum Pidana: Kajian Teoritis Tentang Undang-Undang No. 11 Tahun 2008 Tentang Informasi Dan Transaksi Elektronik Sebagaimana Diubah Dengan Undang-Undang No. 19 Tahun 2016," HUMANI (Hukum dan Masyarakat Madani) 8, no. 2 (2018): 161-176.
} 
Technology wisely ${ }^{11}$, unharmonized school environment, lack of parents supervision, lack of mindset and self-defense and unlimited access of social media ${ }^{12}$. This condition makes bullying will be worse and escalated into a cyberbullying ${ }^{13}$. Cyberbullying is also supported with uneducated shows for the audience. Furthermore, many unsecured contents from internet are need to research for make sure the content is well -educated for society ${ }^{14}$.

It goes horrible with unpredictable ending of Covid-19 pandemic and also become inseparable with cyberbullying because the relation between generation $\mathrm{Z}$ toward technology is also inseparable, it will increasing the negative impact of social media.

As a school with Ahlu Sunnah wal Jamaah orientation, Nusantara Islamic Middle School Malang forms Islamic character that build from the combination of Science, Technology, Beliefs and Taqwa. It reflected with their vision and mission that built, for instance learning developing and mentoring intensively with Islamiah Amaliah Ahlusunnah Waljamaah and good manner orientation and also to bring up the young generation of Nahdlatul Ulama. To equip students with the development of science and technology, students should be able to operate it based on scientific rules through good processing, reasoning, and presentation. Moreover, developing education with entrepreneurship life skill oriented, participatory and transparent management skill, and also designing and implementing effective and efficient learning based on a curriculum based on Muslim entrepreneurs.

In terms of age, SMAINUS students in Malang are categorized on Generation Z, that vulnerable with cyberbullying because all students are sleep over in the Islamic Boarding School near their school. This condition can create cyberbullying between students.

According to the questionnaire data and preliminary study, most of students are cyberbullying victim, it found that some students became a cyberbullying suspects and cyberbullying victim. Although the form of cyberbullying was not aiming to mental and physical, fear, psychological disturbance, revenge and life endanger, this condition will getting worse if cyberbullying do not carry out with appropriate and measurable treatment.

It was known that partner did not have enough knowledge about how to role him/herself as an individual who is able to prevent bullying. It caused by their

${ }^{11}$ Susanti, "Sosialisasi Bahaya Cyberbullying Pada Remaja (Perspektif Islam Dan Patologi Sosial )."

12 Sri Rejeki, "Pendidikan Psikologi Anak "Anti Bullying" Pada Guru-Guru PAUD," Dimas: Jurnal Pemikiran Agama untuk Pemberdayaan 16, no. 2 (2016): 235.

13 Nassharih Abdulloh and Ahmad Fathan Hidayatullah, "Deteksi Cyberbullying Pada Cuitan Media Sosial Twitter," Automata Vol 1, no. 1 (2019): 1-5. Sosial )."

${ }^{14}$ Susanti, "Sosialisasi Bahaya Cyberbullying Pada Remaja (Perspektif Islam Dan Patologi 
limitation of knowledge about bullying prevention, whether becoming victim or just watching it until victim becomes traumatized.

Therefore, it is very important to educate on how to use social media wisely or often called smart social media and education about proper self-defense. The education is to understand the impact of cyberbullying through The Law Number 11 Year 2008 About Information and Electronical Transaction. It gives education about security of Electronic Information Systems or Electronic Documents, and abuses in the field of technology and electronic transactions by cyber bullying suspects.

Moreover, education about self-defense through Islamic Religion while using social media wisely from Koran and Hadith. Furthermore, it was strengthened through an understanding of the Fatwa of the Indonesian Ulema Council number: 24 of 2017 concerning Law and Guidelines for Bermuamalah through social media. The education begins with the meaning of cyber bullying in the Qur'an, which is described as making fun of behavior (Surah Al-Hujurat: 11), prohibiting spreading prejudice and suspicion, looking for bad people, and gossiping (QS. An -Nur: 16). The meaning of cyber bullying in the hadith, among others narrated by Bukhari and Muslim from Abu Hurairah, that cyber bullying means backbiting, then the Prophet's prohibition against hasty behavior, including rushing to spread information before there is clarity (HR. Baihaqi

However, SMAINUS students that majority is Generation Z, will obtain integral understanding from point of view of positive law. Then, students of SMAINUS can more wiselu while operating social media.

\section{Method}

This mentoring were conducted toward students from XI-XII Senior High School of Islam Nusantara in Malang that located in Malang Jl. Mayjen Haryono XXI/30, Dinoyo, Kec. Lowokwaru, Kota Malang, Jawa Timur 65144a. There are 63 students, most of them have been victims of cyberbullying, some have been treated and some have been victims and perpetrators. Most of these students also live in dormitories provided by the school, this dormitory is not far from the school. The location of the hostel is also close to the city center, so students can easily access information.

The great approach for helping problem that faced by students is to educate the students about cyberbullying. It hopes that students can be more carefully while making some interactions with other students to prevent cyberbullying from inside or outside the school. Education is participative model. Sudjana explained that participative model is a learning activity based on the participation of participant in all activity aspects. However, these mentoring activities are focusing on active motivation with participant, question and answer, discussion and reflection. Not only knowledge transfer such as lecturing on Zoom application.

For further details, problem solving about cyber bullying are describe as follows. The first session is brainstorming about what cyberbullying is. On the last 
identification, the team is showing posters that contain with picture and its explanation about kind of cyberbullying, presentation slide and flyer about the danger of bullying. Before moving to the next session, the participants were asked to reflect on which types of bullying are commonly encountered in school environment.

Second session, participants were requested to identify the cause of cyber bullying, especially students. On the last session, team is showing posters that contain with picture about Cyberbullying factor through presentation slide and flyer. Before moving to the next session, the team is giving explanation from Power Point about what wilk students do if: (1) Become cyberbullying victim (2) Seeing friends that being bullied (3) Bullying trauma (4) To find out friend which is not being bullied. The team was divided based on their specialty as follows:

1) Pinastika Prajna Paramita, SH., MIL, as the Leader of Mentoring of Cyberbullying Education.

2) Isdiyana Kusuma Ayu, S.H., M.Kn, as a member of the service provide education about the legal impact of Cyberbullying behavior in Law Number 19 of 2016 concerning Amendments to Law Number 11 of 2008 concerning Information and Electronic Transactions.

3) Dr. Muntaha, S.S., M.Pd.I, as amember that providing Islamic Cyberbullying education and Fatwa of Indonesian Ulama Council Number 24 year 2007 about Law and Guidelines for human relationship through Social Media. Method that conducted can be seen on table 1: Social Mentoring. 


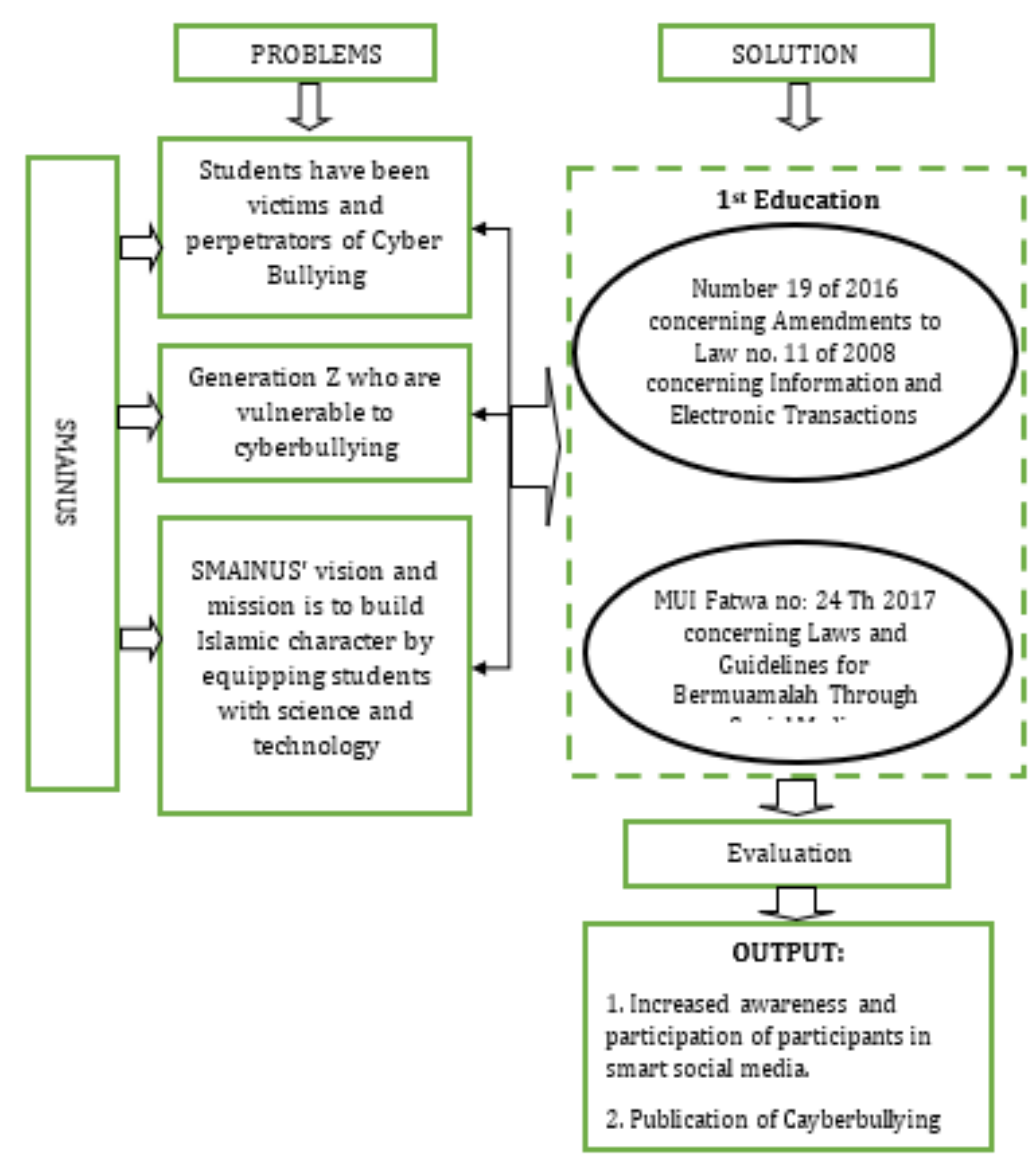

\section{Result}

As an effort to achieve results target, the participatory model of education on its implementation, students were given through brainstorming, lecture and worksheet. Lecturing were used to comprehend the essential concepts by students about cyberbullying. This method was conducted based on the consideration that the lecture method provides an opportunity to convey relatively large amounts of material in a dense, fast, and easy manner. In detail, the implementation of education is divided into two sessions.

The first session was to educate about the meaning, types, causes, and punishments of cyberbullying according to the ITE Law and Islamic Teachings (MUI Fatwa no: 24 Th 2017 on Law and Guidelines for Human Relation Through social media). This session begins with brainstorming about the meaning of bullying, then followed by identifying the forms and types of bullying together which are commonly encountered and/or conveyed by students in the school environment. Furthermore, brainstorming on the causes of bullying behavior and its dangers, including punishment according to the provisions of the ITE Law and according to Islamic teachings. At the end of the session, the team showed posters containing pictures and explanations about the meaning, types, causes, and dangers of bullying through 
presentation slides and leaflets accompanied by explanations of cyberbullying punishments.

The main activities are narrated as follows. After the participants were given the opportunity to expressed what are they comprehend so far about cyberbullying and its types, then a presentation or explanation was given using various lectures about what cyberbullying and its. On this occasion, participants were given an explanation and keywords to be able to distinguish bullying behavior from other behaviors, by explaining that cyberbullying is a form of suppression or violence that is intentionally carried out by one or a group of people who are stronger or more powerful towards another person, aiming to hurt and dominate. The keyword that is emphasized is that it is carried out continuously, if the behavior that being conducted only once, it cannot be categorized immediately as cyberbullying.

In addition, it also explained that bullying was not only happened in cyber but also in physical, verbal and relational forms. Physical abuse in the form of hitting, slapping, spitting or any form of violence that used by physical, including hurt another person and stealing other's belongings on purpose. Cyberbullying has many actions that hurt others from electronic media such as video recordings of intimidation, defamation through social media, etc.). Bullying in the form of verbal in the form of reproach, slander, or the use of words that are not good for hurting others, including saying something that is not right in the heart, for example threatening, teasing, changing nicknames, making bad comments, etc. Bullying in rational forms in the form of neglect, exclusion, ridicule, and all forms of action to alienate someone from his community.

The next activity is identifying and reflecting by distribute a checklist list to participants that contains various types of bullying and then asking participants to sort (give a serial number) according to what students find most often or are informed about in the school environment. From this reflection, it can be concluded that the most often found or informed by students are verbal bullying, then relational bullying, then physical bullying, and finally cyber bullying. Even though the comments in the column provided, participants said that these various forms of bullying generally started from social media through expressions of reproach and bad words that led to relational and even physical bullying.

At the end of the first session, brainstorming was carried out again by asking participants to expressed the caused they know from bullying, including the dangers of bullying. After that, a presentation or explanation is given using various lectures on the causes of bullying, what are the dangers of bullying and the punishment for bullying referring to the UU-ITE and Islamic Teachings (Fatwa). MUI no: 24 Th 2017 concerning Law and Guidelines for Bermuamalah Through Social Media).

The education based on ITE Law is a) Article 27 paragraph (3) with elements of a criminal act: distributing and/or transmitting and/or making accessible Electronic 
information and/or Electronic Documents containing insults and/or defamation. good; b) Article 27 paragraph (4) with elements of a crime: distributing and/or transmitting and/or making accessible Electronic information and/or Electronic Documents containing extortion and/or threats; c) Article 28 paragraph (2) with elements of a criminal act: disseminating information aimed at causing feelings of hatred or hostility to certain individuals and/or community groups based on ethnicity, religion, race, and inter-group (SARA); d) Article 29 with elements of a criminal act: sending Electronic information and/or Electronic Documents containing threats of violence or intimidation aimed at personally; d) Article 30 paragraph (1) with elements of a crime: accessing Computers and/or Electronic Systems belonging to other Persons in any way; and e) Article 32 paragraph (2) with elements of a criminal act: transferring or transferring Electronic Information and/or Electronic Documents to the Electronic system of another person who is not entitled.

On the other hand, the educational material of Islamic teachings is about the prohibition of cyberbullying in Islam, especially as formulated by the Council of Indonesian Ulama no: 24 Th 2017, that the main sources of Islam, namely the Qur'an, As-Sunah, Ijma' and Qiyas is also provide education about cyberbullying. The Qur'an gives hints about cyberbullying including, QS: Al-Hujurat:11, explaining the prohibition of criticizing and belittling others by giving bad nicknames and make other people feel ashamed and angry, QS: Al-Humazah:1, about the prohibition of criticizing and cursing, QS: At-Taubah: 79, about the behavior of hypocrites who criticize, criticize, and insult others even though that person does the right thing, QS: Al-Ahzab: 58, about the behavior of hurting others by If He did not commit a sin, then those people had sinned. And QS: Al-An'am: 10, about the reward that will be given by Allah SWT to people who like to make fun of or ridicule others, Allah will give them a worth recompense or punishment. The explanation of the verses of the Qur'an above proves that in fact related acts of bullying have been arranged by Allah in his holy book as a guide for Muslims. The acts described in the verses above such as criticizing, belittling, mocking, and insulting are bullying activities.

Cyberbullying in the Hadith is also needs to comprehend, especially in the Hadith narrated by Bukhari from Abdullah bin Umar, and Abu Daud from Abu Hurairah, the Messenger of Allah forbade backbiting, looking for disgrace to his brother, and complicating his brother's affairs.

As the third source of Islamic law, Qiyas, which is based on a measure that comes from the human mind to compare things that are not contained in the Qur'an and Sunnah with things that have the same reasons and have been regulated in legal sources. the Islam. In this case, cyberbullying that conducted by reproach, making fun of, mocking with negative connotations may resulting bad impact on the victim, including the category of unjust acts which in Islam is strongly opposed because it is a sinful act and it is unlawful to be done by Muslims because it can cause enmity 
between human.

Beside that, it is also necessary to comprehend the importance of cyberbullying and its effects in the opinion from ulama, as follows 1) Imam al-Qurtubi explained that gossip is a part of cyberbullying which is like eating the flesh of his own brother who is dead because the dead cannot know if the meat is eaten by someone else. others, such as when he lived not knowing people were gossiping about him; 2) Imam Nawawi regarding the Hadith of hasty behavior in spreading any news that comes to him. According to him, the meaning of this hadith is a warning from conveying every information that a person hears, because usually he hears true and false news, so if he conveys everything he hears, it means he has lied because he conveyed something that did not happen.

On this opportunity, participants were also given an explanation that people were conducting bullying is generally triggered or caused by four main factors as follows (1) conflict and irritate; (2) Unconfident and shows off, it means that someone who is unconfident want to be noticed by bullying. By doing it, they will feel satisfied, stronger, and dominant; (3) Revenge, it means that someone who had been hurt or being bullied is usually hold a revenge that needs to be wrecked to others so that other people feel the same way and (4) the negative influence from the media, it means that many contents of violence in the media for instance television, internet, and others become bad examples that inspire someone to commit violence for no reason. In addition, it was also explained that bullying can cause fear and psychological disturbances, lead to revenge even endanger lives or lead to death.

To anticipate the dangers of bullying, various data and information that happening around the world have been presented, namely that every day 160,000 students are dropped out for fear of being bullied; 1 in 10 students change schools for fear of being bullied; research has found that people who are bullied are more likely to experience difficulties in the work environment; people who had been bullied also reported having difficulty maintaining long-term friendships and good relationships with their parents; and research concludes that those who are bullied can bully themselves so as to endanger themselves; $40 \%$ of child suicides in Indonesia are due to bullying. At the end of this session, it was also explained that acts of bullying which are sometimes considered trivial and become commonplace, are actually criminal acts because they violate human rights so that they can be punished and sinful in the eyes of Islam.

First session, in order to educate, it is also used to track participants' initial abilities (entry hebavior) by observing the number of participating students including the suitability of the answers with the content of the questions given. Through brainstorming activities, it appears that in general participants have an inaccurate understanding of bullying. For example, most argue that bullying is only physical violence. Most of the students also do not understand if cyberbullying has legal 
implications. Likewise, if bullying is seen from an Islamic point of view, most students do not understand that cyberbullying is the same as slander.

According to the results of brainstorming and evaluation through questionnaires, students stated that they were understood that cyberbullying was an action that was not only done verbally in cyberspace, but physically, verbally, relationally. Most of them said that they know what cryberbullying is, the forms of cyberbullying, and how to deal with cyberbullying. Others explained that they could and knew how to control their words to others without hurting them, and also learned how to use social media properly and wisely. This expression is the result of reflection of students who have been perpetrators of cyberbullying.

\section{Discussion}

At the first time, the students are not understanding about cyberbullying. In general, the students are considering that cyberbullying are normal behavior and jokes on social media. This kind of understanding is very worrying, because it can have serious physical and psychological impacts. According to Jan and Husain this behavior is included in the category of bullying. In this case bullying is defined as all behavior that is considered painful, acts of physical violence, name-calling ridicule, social exclusion, spreading false rumors ${ }^{15}$. Specifically, Widiyanti defines it as a type of aggressive behavior that is intended to hurt or annoy, which is repeated from time to time, and there is an imbalance of power, namely the strong attacking the weak ${ }^{16}$.

The understanding of students who consider it as an ordinary joke, it may increase as physical illness ${ }^{17}$, then develops into feelings of unhappiness, pain and humiliation, confusion, distress, loss of self-esteem, anxiety, insecurity, and loss of concentration, contributing to low attendance and low academic achievement ${ }^{18}$. If this situation continues and repeats itself, it can cause serious social problems, including increased juvenile delinquency, adult crime $^{19}$, domestic violence, and suicide ${ }^{20}$.

In addition, cyberbullying has higher impact than other bullying, for instance verbal bullying. It caused those victims of cyberbullying has a higher level of depression than verbal violence. In cyberbullying, the suspect can hide his true identity in order ease for the suspect to bully the victim without having to see the victim's physical response.

In positive law, cyberbullying against children is a crime so that the perpetrator

${ }^{15}$ M S Afroz Jan and Shafqat Husain, "Bullying in Elementary Schools: Its Causes and Effects on Students," Journal of Education and Practice 6, no. 19 (2015): 43-57.

16 Wiwied Widiyanti, "Mengenal Perilaku Bullying Di Sekolah," Jurnal Bimbingan dan Konseling Islam 3, no. 1 (2019): 55-68.

${ }^{17}$ Budiati et al., Statistik Gender Tematik: Profil Generasi Milenial Indonesia.

18 Saripah and Pratita, "Kecenderungan Perilaku Cyberbullying Peserta Didik Berdasarkan Jenis Kelamin."

19 Ibid.

${ }^{20}$ Budiati et al., Statistik Gender Tematik: Profil Generasi Milenial Indonesia. 
should be arrested to the police with the assistance of related parties. As regulated in the Child Protection Act, Number 35 of 2014, Article 76 C jo. Article 80 (1) "Everyone is prohibited from placing, allowing, doing, ordering to do, or participating in committing violence against children"

Meanwhile, from an Islamic perspective, cyberbullying that can have a negative impact on the victim's psychology, such as rebuking, criticizing, making fun of, scaring, mocking with bad connotations, is categorized as an act or criminal act (jinayah) in Islam, which is a prohibited act. Cyberbullying perpetrators will be subject to sanctions and/or punishments according to jarimah Ta'zir', the amount of which is determined by the authorities when in the world, and will be given a painful punishment by Allah in the hereafter because these actions are included in the sins committed and/or committed by other people 21 .

From the results of brainstorming and evaluation through questionnaires, after educating students who incidentally as Gen Z stated they understood and understood that cyberbullying is a verbal act that is carried out using social media, and has legal and religious implications. In general, they stated that after attending this education, they understood cyberbullying, forms of cyberbullying, how to deal with cyberbullying, and understood how to use social media properly and wisely in order to avoid the snares of state law and the law of Allah SWT. Some also stated that in the form of soul expression, including understanding how to control words to others without hurting their hearts, being more careful in their words. ${ }^{22}$

As generation $\mathrm{Z}$, they were born when access to information has become a global culture, so this condition greatly affects their values, views and life goals ${ }^{23}$. This period is a period of transition to adulthood, Gen Z prefers to try something that they think will be accepted by their friends or environment. One way is to be active on social media. Generally, on social media is where they express themselves. Gen Z characters who are predominantly aggressive are not uncommon if the joke leads to cyberbullying behavior such as opening a friend's account without the owner's permission, editing photos with the aim of humiliating. This is of course driven by the low attitude of mutual respect for each other. Therefore, it is necessary to conduct education that is right on target and can be accepted by this generation.

The education is participatory model ${ }^{24}$. In its implementation, students are given knowledge through various lecture methods, brainstorming, worksheets as individual exercises. Lectures are used to convey essential concepts that need to be

21 Winda Fitri and Nadila Putri, "Kajian Hukum Islam Atas Perbuatan Perundungan (Bullying) Secara Online Di Media Sosial," Pendidikan Kewarganegaraan 9, no. 1 (2021): 143-157.

${ }^{22}$ Rangga Sa'adillah S.A.P., Dewi Winarti, and Daiyatul Khusnah, "Kajian Filosofis Konsep Epistemologi Dan Aksiologi Pendidikan Islam," Journal of Islamic Civilization 3, no. 1 (2021): 34-47.

23 Putra, "Theoritical Review: Teori Perbedaan Generasi." 2010).

24 Djuju Sudjana, Metode Dan Teknik Pembelajaran Partisipatif (Bandung: Falah Production, 
understood and mastered by students regarding cyberbullying. The use of this method is based on the consideration that the lecture method provides an opportunity to convey relatively large amounts of material in a dense, fast, and easy manner ${ }^{25}$. The material presented is in accordance with the needs of students as partners, after being given education about the meaning of cyberbullying. It is also very important to be educated regarding the legal impact. Students feel that so far, they have not understood that cyberbullying has legal implications. Most of them stated that they would be more careful in social media and take care of their talks.

The purpose of Law of Information and Electronic Transaction is to guarantee the recognition and respect for the rights and freedoms of others and to fulfill fair demands in accordance with considerations of security and public order ${ }^{26}$. In this case, to protect against unlawful actions and words, as stated in the UU-ITE, among others: a) distributing and/or transmitting and/or making accessible electronic information and/or Electronic Documents containing insults and/or defamation. good (Article 27 paragraph 3); b) distribute and/or transmit and/or make accessible Electronic information and/or Electronic Documents containing extortion and/or threats (Article 27 paragraph 4); c) disseminating information aimed at causing hatred or hostility to certain individuals and/or groups of people based on ethnicity, religion, race, and inter-group (SARA) (Article 28 paragraph 2); d) sending Electronic information and/or Electronic Documents containing threats of violence or intimidation aimed at personally (Article 29); d) accessing Computers and/or Electronic Systems belonging to other Persons in any way (Article 30 paragraph 1); and e) transfer or transfer Electronic Information and/or Electronic Documents to the Electronic system of other unauthorized persons (Article 32 paragraph 2)

According to Islam, the change in the understanding of students who will be careful in accessing social media and speech are very important in Islamic teachings, as emphasized by its urgency in the main sources of Islamic law, namely the Qur'an, As-Sunnah, Ijma' and Qiyas. The Qur'an gives hints about cyberbullying including, QS: Al-Hujurat:11, explaining the prohibition of criticizing and belittling others by giving bad nicknames and can make other people feel ashamed and angry, QS: Al-Humazah:1, about the prohibition of criticizing and cursing, QS: At-Taubah: 79, about the behavior of hypocrites who criticize, criticize, and insult others even though that person does the right thing, QS: Al-Ahzab: 58, about the behavior of hurting others by If He did not commit a sin, those people had sinned. And QS: Al-An'am: 10, about the reward that will be given by Allah SWT to people who like to make fun of or ridicule others, Allah

25 Suardi and Samad, "Edukasi Pencegahan Perundungan."

26 Presiden Republik Indonesia, Undang-Undang Republik Indonesia Nomor 19 Tahun 2016 Tentang Perubahan Atas Undang-Undang Nomor 11 Tahun 2008 Tentang Informasi Dan Transaksi Elektronik (Jakarta, 2016). 
will give them a recompense or punishment in kind ${ }^{27}$. The description of the verses of the Qur'an above proves that in fact related acts of bullying have been arranged by Allah in his holy book as a guide for Muslims. ${ }^{28}$

In the Hadith of the urgency of understanding students, it is also stated in the Hadith narrated by Bukhari from Abdullah bin Umar, and Abu Daud from Abu Hurairah, Rasulullah SAW forbade backbiting, looking for the disgrace of his brother, and complicating his brother's affairs ${ }^{29}$.

However in qiyas, the understanding of students which are they understand how to use social media wisely and prevent hurtful speech, the urgency can be traced from the rule as a source of Islamic law, which is based on a measure that comes from the human mind to compare a matters that are not regulated in the Qur'an and AsSunnah with the same reasons and have been regulated in the sources of Islamic law. In this case, cyberbullying which is carried out by criticizing, ridicule, mocking with negative connotations that can have a bad impact on the victim is included in the category of unjust acts which in Islam is strongly opposed because it is a sinful act and it is unlawful to be done by Muslims because it can cause enmity between them (humans) ${ }^{30}$.

Apart from the Main Source of Islamic Teachings, the urgency of understanding the students was also emphasized by the scholars, including 1) Imam al-Qurtubi in explaining backbiting as part of cyberbullying which is like eating the flesh of his own dead brother because the dead cannot know that the meat is eaten by others, as when he lived not knowing people were gossiping about him; 2) Imam Nawawi when giving a syarah about Hadith, the behavior of rushing to spread any news that comes to him. According to him, the meaning of this hadith is a warning from conveying every information that a person hears, because usually he hears true and false news, so if he conveys everything he hears, it means he has lied because he conveyed something that did not happen.

Although Islam also provides exceptions for the permissibility of cyberbullying, which is confirmed from the opinion of Imam Nawawi who allows swearing and telling disgrace because of a goal that is considered correct in the view of Islamic Shari'a, provided that this goal will not be fulfilled if swearing and telling disgrace is not carried out. These objectives are categorized into six types: First, At-tazhallum, namely complaints of injustice that befell, the wronged person may mention someone's

27 Muhammad Quraish Shihab, Tafsir Al-Misbah Pesan, Kesan Dan Keserasian Al-Quran, III. (Tangerang: Lentera Hati, 2005).

28 Daiyatul Khusnah and Dewi Winarti, "PSIKOLOGI HUMANIS; Mengurai Relasi Teoritik Antara Psikologi Dan Agama," EL-BANAT: Jurnal Pemikiran dan Pendidikan Islam 11, no. 1 (2021): 17-36.

${ }^{29}$ Majelis Ulama Indonesia, Fatwa Majelis Ulama Indonesia Nomor: 24 Tahun 2017 Tentang Hukum Dan Pedoman Bermuamalah Melalui Media Sosial (Indonesia, 2017).

30 Fitri and Putri, "Kajian Hukum Islam Atas Perbuatan Perundungan (Bullying) Secara Online Di Media Sosial." 
injustice against himself and complain to law enforcement officials and parties who have the competence and capacity (qudrah) to awaken the wrongdoers. . Second, alisti'anah, which is asking for help, to change the evil and return the actions of disobedient people to the truth, such as saying to people who are expected to be able to eliminate evil: "So and so have done this (bad deed). Prevent him." Third, Al-Istifta', which is asking for a fatwa, asking for a fatwa and advice. like the words of a requester for advice to the mufti (giver of fatwa): "I was wronged by my father or brother, or husband..." Fourth, at-tahdzir, namely warning, reminding Muslims of bad deeds and giving advice to them. Fifth, people who show ungodliness and immoral behavior. Sixth, give a certain nickname to someone. If someone is already known by certain nicknames such as al-A'ma (the blind), al-a'sham (the mute) then that's okay. However, it is forbidden to mention a nickname if it is to show weakness ${ }^{31}$.

Thus, changes in students' understanding that cyberbullying is a verbal act that is carried out using social media, and has legal and religious implications, can provide behavioral changes in how to use social media properly and wisely in order to avoid the snares of state law and the law of Allah SWT. And being a controller of words to others without hurting his heart, being more careful in saying

\section{Conclusion}

Cyberbullying is a form of violence that is carried out intentionally or unintentionally with the aim of hurting other people's hearts or physically harming is strictly prohibited both under Positive Law in Indonesia and is not allowed in Islam because it has an individual and social impact. If education is not carried out immediately, it can have an impact on increasing juvenile delinquency, adult crime, domestic violence, to suicide, it can also cause hostility among the people and can break friendship

Education about cyberbullying with a participatory pattern from the point of view of positive law and Islamic teachings is very effective given to students who incidentally are Generation Z, a generation that cannot escape the media world. So that this generation is able to use social media as a medium for selfdevelopment and success in life in the future

\section{Acknowledgements}

The acknowledgement especially to the Chancellor of the Islamic University of Malang, the Dean of the Faculty of Law Unisma, the Head of LP3M, the Head of

31 Al-Iman Abu Zakaria Yahya bin Syaraf An-Nawawi, Terjeman Riyadus Shalihin Jilid 2, ed. Husin Abdullah, Edisi Revi. (Jakarta: Pustaka Amani, 1999). 
SMAINUS Malang who have provided assistance in this service activity. We would also like to thank the students of SMAINUS Malang for their excellent cooperation, and to those who have assisted in the implementation of this community service.

\section{References}

Abdulloh, Nassharih, and Ahmad Fathan Hidayatullah. "Deteksi Cyberbullying Pada Cuitan Media Sosial Twitter." Automata Vol 1, no. 1 (2019): 1-5.

An-Nawawi, Al-Iman Abu Zakaria Yahya bin Syaraf. Terjeman Riyadus Shalihin Jilid 2. Edited by Husin Abdullah. Edisi Revi. Jakarta: Pustaka Amani, 1999.

Badan Pusat Statistik. Hasil Sensus Penduduk 2020. Jakarta Pusat, 2021.

Budiati, Indah, Yusi Susianto, Widhiarso Ponco Adi, Sofaria Ayuni, Henri Asri Reagan, Putri Larasaty, Nia Setiyawati, Aprilia Ira Pratiwi, and Valent Gigih Saputri. Statistik Gender Tematik: Profil Generasi Milenial Indonesia. Jakarta Pusat: Kementerian Pemberdayaan Perempuan dan Perlindungan Anak, 2018.

Fitri, Winda, and Nadila Putri. "Kajian Hukum Islam Atas Perbuatan Perundungan (Bullying) Secara Online Di Media Sosial." Pendidikan Kewarganegaraan 9, no. 1 (2021): 143-157.

Jan, M S Afroz, and Shafqat Husain. "Bullying in Elementary Schools: Its Causes and Effects on Students." Journal of Education and Practice 6, no. 19 (2015): 43-57. Juita, Subaidah Ratna, Amri Panahatan Sihotang, and Ariyono. "Cyber Bullying Pada Anak Dalam Perspektif Politik Hukum Pidana: Kajian Teoritis Tentang Undang-Undang No. 11 Tahun 2008 Tentang Informasi Dan Transaksi Elektronik Sebagaimana Diubah Dengan Undang-Undang No. 19 Tahun 2016." HUMANI (Hukum dan Masyarakat Madani) 8, no. 2 (2018): 161-176.

Khusnah, Daiyatul, and Dewi Winarti. "PSIKOLOGI HUMANIS; Mengurai Relasi Teoritik Antara Psikologi Dan Agama." EL-BANAT: Jurnal Pemikiran dan Pendidikan Islam 11, no. 1 (2021): 17-36.

Majelis Ulama Indonesia. Fatwa Majelis Ulama Indonesia Nomor: 24 Tahun 2017 Tentang Hukum Dan Pedoman Bermuamalah Melalui Media Sosial. Indonesia, 2017.

Presiden Republik Indonesia. Undang-Undang Republik Indonesia Nomor 19 Tahun 2016 Tentang Perubahan Atas Undang-Undang Nomor 11 Tahun 2008 Tentang Informasi Dan Transaksi Elektronik. Jakarta, 2016.

Putra, Tanuar Surya. "Theoritical Review: Teori Perbedaan Generasi." Among Makarti 9, no. 18 (2016): 123-134.

Rejeki, Sri. "Pendidikan Psikologi Anak "Anti Bullying" Pada Guru-Guru PAUD." Dimas: Jurnal Pemikiran Agama untuk Pemberdayaan 16, no. 2 (2016): 235.

S.A.P., Rangga Sa'adillah, Dewi Winarti, and Daiyatul Khusnah. "Kajian Filosofis Konsep Epistemologi Dan Aksiologi Pendidikan Islam." Journal of Islamic Civilization 3, no. 1 (2021): 34-47.

Saripah, Ipah, and Ajeng Nurul Pratita. "Kecenderungan Perilaku Cyberbullying Peserta Didik Berdasarkan Jenis Kelamin." Pedagogia: Jurnal Ilmu Pendidikan 16, no. 3 (2018): 180-192.

Shihab, Muhammad Quraish. Tafsir Al-Misbah Pesan, Kesan Dan Keserasian AlQuran. III. Tangerang: Lentera Hati, 2005. 
Suardi, and Sulaiman Samad. "Edukasi Pencegahan Perundungan." In Seminar Nasional Hasil Pengabdian Kepada Masyarakat "Peluang Dan Tantangan Pengabdian Kepada Masyarakat Yang Inovatif Di Era Kebiasaan Baru," 569. Makasar: Universitas Negeri Makasar, 2020.

Sudjana, Djuju. Metode Dan Teknik Pembelajaran Partisipatif. Bandung: Falah Production, 2010.

Susanti, Ari. "Sosialisasi Bahaya Cyberbullying Pada Remaja (Perspektif Islam Dan Patologi Sosial )." Jurnal Pengabdian Masyarakat Ipteks 6, no. 1 (2020): 21-27.

Widiyanti, Wiwied. "Mengenal Perilaku Bullying Di Sekolah.” Jurnal Bimbingan dan Konseling Islam 3, no. 1 (2019): 55-68. 